\title{
Impact of Climate Change on Food Security and Its Mitigation Using Modern Biotechnology
}

\author{
Omena Bernard Ojuederie* and Kayode Ezekiel Ogunsola \\ Department of Biological Sciences, Bells University of Technology, Nigeria
}

Submission: February 09, 2017; Published: April 04, 2017

*Corresponding author: Ojuederie OB, Department of Biological Sciences, Bells University of Technology, P.M.B. 1015, Benja, Ota, Ogun State, Nigeria, Tel: +23480-7592-7894; Email:omenabernojus@gmail.com

\begin{abstract}
Climatic changes caused by green house gas emissions over the years have adversely affected the environment and added more pressure to agricultural production. Continuous increase in greenhouse gas emissions causes global warming which leads to melting of glaciers, unpredictable rainfall patterns, and extreme weather conditions. This could have a negative effect on global food security. Food insecurity and hunger could affect human health and cause economic development problems depriving the basic necessities of life. This review discussed the causes of climate change and its impact on food security in Sub Saharan Africa with focus on Nigeria.

Modern biotechnology could aid agricultural production while mitigating the effects of climate change by the adoption of herbicidetolerant crops which permit farmers to substitute application of broad spectrum herbicides and insect resistant biotech crops which require fewer pesticide sprays, significantly reducing soil carbon sequestration and $\mathrm{CO}_{2}$ emissions. The modified crops reduce the need for tillage or ploughing to allow farmers to adopt no- till farming practices. Nitrogen efficient modified crops reduce the need for fertilizer application which invariably reduces greenhouse gas (GHG) emissions.

It is important for biosafety regulatory systems to be established and good policies formulated on agricultural development with the use of sustainable agricultural biotechnology with public-private partnership to effectively utilise modern biotechnology to enhance food security and mitigate climatic changes. This will ensure that the crops released are environmentally safe and have no adverse effect on man and the environment.
\end{abstract}

Keywords: Climate change; Biosafety; Food security; Green house gases; Genetically modified crops; Modern biotechnology

\section{Introduction}

According to the Food and Agriculture Organization [1] statistics, over $25 \%$ of the world's 925 million hungry people live in sub-Saharan Africa. Half of the world's hungry are from smallholder farming communities, living on marginal lands that are vulnerable to the effects of climate change [2]. Yet in Africa, smallholder farmers produce nearly $90 \%$ of the continent's total food output. The global food system does not yet provide adequate calories or nutrition to everyone on the earth, but it enables some populations to over consume while others are malnourished. Of the world's estimated 7,000 million people, 500 million still suffer from protein-energy malnutrition, but over 1,600 million suffer from iron deficiency, over 200 million from vitamin A insufficiency [3] and it has been estimated that over 400,000 children die each year from effects directly related to zinc deficiency [4]. The widespread uptake of sustainable practices in agriculture and food supply chains is essential to meet current and future threats to food security and environmental resilience.
In the future, global agriculture must produce more food to feed the growing population, while adapting to climate change, an increasing threat to all elements essential for life. Climate change is adding pressure to agricultural production. Agricultural practices such as deforestation, inorganic fertilizer use and overgrazing currently account for about $25 \%$ of green house gases $\left(\mathrm{CO}_{2}, \mathrm{CH}_{4}\right.$ and $\left.\mathrm{N}_{2} \mathrm{O}\right)$ emission [5] and this causes global warming and changes in climate. In order to meet global food demands, farmers are challenged with drought, flooding and excessive temperatures but sustainable and efficient agricultural tools and practices can help mitigate the erratic weather patterns. Agriculture needs to be climate ready in order to meet up with food security. Apart from stopping the felling of trees, reducing combustion from automobiles and gas flaring, modern biotechnology has been identified as a technology of the $21^{\text {st }}$ century that would drastically reduce green house gas emissions thereby mitigating the effects of climate change. 
Reports have been made on the production of herbicidetolerant crops to reduce soil carbon sequestration [6-10], reduction in pesticide application due to insect resistant crops containing the Bt gene [11], salt tolerant crops [12], drought tolerant crops [13-16] as well as biofuels to reduce the adverse effects of $\mathrm{CO}_{2}$ emission from automobiles [17-20]. These have drastically assisted in mitigating the effects of climate change. Despite the gains of modern biotechnology in this regard, there are skepticisms on the use of the technology especially in developing countries which are more affected by climate change. More sensitization need to be carried out to enlighten the populace on the benefits of biotechnology in enhancing food security while mitigating the effects of climate change. This will enhance agricultural productivity and boost food security. The major aim of agricultural biotechnology is to enhance productivity and maximize productive capacity of diminishing resources. This paper seeks to highlight the potentials of modern biotechnology in mitigating the negative effects of climate change and its impact on food security.

\section{Climate Change}

Climate change refers to a broad array of alterations in climatic and weather conditions characterized by shifts in average conditions and in the frequency and severity of extreme conditions [21]. Rises in average temperature, changes in rainfall patterns, thawing of glaciers and other changes are consequences of climate change. The Intergovernmental Panel on Climate Change (IPCC) predicted that the global surface temperature will increase by $1.4-5.8{ }^{\circ} \mathrm{C}$ by 2100 years due to increasing concentration of greenhouse gases (GHGs) especially carbondioxide [22] which is largely dependent on fossil energy use and by methane and nitrous oxide emissions from agriculture.

Greenhouse gases (GHGs) are those gaseous constituents of the atmosphere, both natural and anthropogenic, that absorb and emit radiation at specific wavelengths within the spectrum of infrared radiation emitted by the earth's surface, the atmosphere and clouds. Addition of $\mathrm{N}_{2} \mathrm{O}$ in the soil occurs when nitrogen fertilizers applied to crops interact with soil bacteria. It has been estimated that nitrogen fertilizer accounts for onethird of the GHGs produced by agriculture [23,24]. Nitrous oxide $\left(\mathrm{N}_{2} \mathrm{O}\right)$ has a global warming potential (GWP) of 296, which is about 300 times greater than carbon dioxide. This implies that one kilo of nitrous oxide is equivalent to 296 kilos of $\mathrm{CO}_{2}$ [24].

In addition, nitrous oxide stays in the atmosphere for more than 100 years. Reducing the use of fertilizer will invariably reduce nitrogen pollution of ground and surface waters. Human activities also release GHGs into the atmosphere for example, from power stations, automobiles, industrial factories and even old refrigerators. These GHGs over the years have caused a faster change in the world's climate than is natural. Continuous increase in greenhouse gas emissions causes global warming which leads to melting of glaciers, unpredictable rainfall patterns, and extreme weather conditions [10]. Carbon dioxide $\left(\mathrm{CO}_{2}\right)$ has the second-largest direct contribution to the green-house effect of all gases. According to the Global Carbon Project [25] Report, anthropogenic $\mathrm{CO}_{2}$ emissions are growing four times faster since 2000 than during the previous decade, and are above the worst case emission scenario of the Intergovernmental Panel on Climate Change (IPCC). They also point to a decline in the efficiency of $\mathrm{CO}_{2}$ natural sinks ( $5 \%$ decline over past 50 years).

The fifth assessment report of the Intergovernmental Panel on Climate Change (IPPC) released in 2014 pulled together the conclusions of three IPCC working groups, which issued reports over the past year on the underlying science, the impacts, and the ways to address climate change. The report revealed beyond reasonable doubt that the Earth's climate is warming with much impact on African Society [26]. The assessment also showed with $95 \%$ certainty that human activities released greenhouse gases (GHGs) into the atmosphere. This has altered the climate thereby causing global warming since the mid-1970 [26]. These GHGs have caused a faster change in the world's climate than is natural.

\section{Impact of Climate Change on Agricultural Productivity, Human Development and Wellbeing}

A substantial amount of research has been conducted on the potential impacts of climate change on agricultural productivity [27-29]. Green house gases are the major contributors to climate change in agricultural production. Land clearing for agriculture, particularly deforestation, contributes significantly to the impacts of GHGs. The fifth assessment report of IPPC predicted an irreversible impact of climate change on the West Antarctic Ice Sheet which already has begun to collapse and could lead to rise in sea level thereby causing widespread flooding and could have irreversible impact on extinction of plants and animals [26] Continuous increase in greenhouse gas emissions raises air and sea temperatures, which leads to melting of glaciers, unpredictable rainfall patterns, and extreme weather conditions [10] which could greatly affect global food security, water availability and human health significantly in Africa by accelerating the rate of climate change, combined with increasing global population and depletion of agricultural resources.

Climate change is a great challenge to almost all human endeavors because it affects the future ways in which energy will be generated and used and could adversely affect water supplies and agricultural productivity. Globally, most GHG emissions are due to the activities of man and have come from just a few developed countries for example the United States, Japan, United Kingdom, Germany, etc. The fifth assessment report of IPPC also pointed out a total rise of emission since the 1970 with its peak between 2000 and 2010. Green house gas emissions grew over $2.2 \%$ per year compared to $1.3 \%$ per year over the entire period 1970-2000 [26]. If this trend continues unabated, the situation 
could become catastrophic especially for the African continent which is already experiencing severe drought in parts of Nigeria and South Africa. The IPPC also warned that if GHGs are continuously emitted at the current rates by the global society, the average global temperature could rise by $2.6-4.8^{\circ} \mathrm{C}$ by 2100 [26].

It therefore becomes imperative to drastically reduce $\mathrm{CO}_{2}$ emissions to avoid further harmful environmental degradation by the transition from conventional fossil fuels to alternative and renewable resources which is now a global priority. Changing weather patterns could affect how pests and diseases of many crops and of livestock are controlled, which could invariably change how food will need to be stored. Poor storage of fresh foods could lead to health risks like food poisoning which would be a greater danger in rural areas where subsistence agriculture is currently practiced. The impacts of climate change on agriculture vary by region because these are influenced by the technologies used by farmers as technological advancement determines farm productivity far more than climatic and agricultural endowments [30]. The United Nations Environment Programme UNEP [31], has noted that "doubling of wealth leads to $80 \%$ higher $\mathrm{CO}_{2}$ emissions". Therefore, there is an urgent need to break the link between financial growth and increasing emissions at the expense of sustainability. The 2006 report by economist, Nicholas Stern, commissioned by the UK government, warned that temperatures could increase by 2 to 3 degrees in the next fifty years. Among the other worrying consequences of climate change predicted by the Stern Report are declining crop yields, ocean acidification, human malnutrition and crop stress, population displacement and threatened ecosystems. These effects could be particularly dramatic in the light of growing population levels especially in developing countries in sub Saharan Africa.

In order to feed the ever teaming population, the world faces the daunting task of having to double its rate of agricultural production over the next 25 years [32] having already quadrupled it in the last 50 years. Extreme weather events such as droughts and floods could become more frequent, adding to the global burden of hunger caused by poverty, weak governance, conflict and poor market access. The Least Developed Countries (LDCs) are dependent on agriculture, climate sensitive economic sectors, which makes them more vulnerable to the impacts of climate change because of its less resilient to negative external events and low capacity to adapt than other developing countries [33].

\section{Effects of Climate Change in Sub Saharan Africa with Emphasis on Nigeria}

According to Thomton et al. [34], sub-Saharan Africa is estimated to be the most food-insecure region in the future. It is the most susceptible and vulnerable region to climate change and variability anywhere in the world $[35,36,20]$. The situation is becoming more threatening with climate change effects and soaring global food prices which make food importation extremely difficult [37]. Most African countries fall into the category of LDCs and they are vulnerable to climate change as their economies depend majorly on weather-sensitive agricultural production systems [38]. Estimates made by Fischer et al. [39] suggested a possible increase by about 5 to $8 \%(60-90$ million ha) of areas with drought by 2080 in sub-Saharan Africa, a region that contributes very little to climate change (about $2 \%$ of the anthropogenic $\mathrm{CO}_{2}$ ).

Although $60-70 \%$ of the African population depends on agriculture for their livelihoods, agriculture in Africa is highly dependent on rainfall which makes the small holder farmers among the most disadvantageous and vulnerable group [40]. Only about $4 \%$ of cropped land has access to irrigation [41]. About $33 \%$ and $25 \%$ of cropped land are subjected to moderate drought and severe drought, respectively [41] especially in countries like Sudan. Odjugo [42] carried out an overview of climate change impacts in Nigeria for a period of 105 years (1901-2005) using mean annual and monthly temperature and rainfall data collected from the Nigerian Meteorological Agency and some States' airports. The study revealed that there was increasing temperature and decreasing rainfall amount and duration in Nigeria between 1901 and 2005. Temperature increase of $1.1^{\circ} \mathrm{C}$ was observed in Nigeria for the 105 years while rainfall amount dropped by $81 \mathrm{~mm}$. Rainfall amount is generally decreasing in Nigeria with more months of dry season.

The report also showed that the coastal region of Nigeria has been experiencing slightly increasing rainfall since the early 1970s despite the general decreasing rainfall amount in the country. The short-dry-season popularly known as August break is currently being experienced more in the month of July as against August. Sea-level rise was also observed to have inundated $3400 \mathrm{~km}^{2}$ of Nigeria coastal region while desert encroachment is reducing arable lands from the northern part of the country by $1-10 \mathrm{~km}$ a year [42]. In the Niger Delta region and some other parts of Nigeria, the devastating effects of the 2012 flooding were pronounced. Farm lands were destroyed and thousands displaced from their homes.

In Nigeria, some stable ecosystems such as the Sahel Savanna may become vulnerable because global warming is likely to reinforce existing patterns of water scarcity, thereby increasing the risk of drought in northern Nigeria and indeed most countries in West Africa. Also, the country's aquatic ecosystems, wetlands and other habitats will create overwhelming problems for an already impoverished populace [43] Arid and semi-arid areas in northern Nigeria are gradually becoming drier, while the southern regions of the country are getting wetter resulting in annual floods. Global warming implies that many dry areas are going to get drier and wet areas are going to get wetter in the future. The Lake Chad has almost dried up, and persistent desert 
encroachment is ongoing in the north [44].

Some northern states of Nigeria are experiencing severe drought and the Nomadic herdsmen have to migrate towards the South to find forage for their cattle. Sometimes clashes occur with farmers whose crops are destroyed. Rough estimates by IPCC [45]; BNRCC [46] suggested that over the next 50 years, climate change may likely have a serious threat to meeting global food needs than other constraints on agricultural systems. Rain-fed agriculture, which covers $96 \%$ of all cultivated land in sub-Saharan Africa, will be greatly affected. Crop yields in tropical regions are likely to decline even for small increases in temperature. According to IPPC [45], agriculture and land use changes emits $31 \%$ of GHGs due to deforestation, bush burning, over grazing as well as agricultural practices such as the use of pesticides and farm machinery in mechanized agriculture. The over-all impact of climate change as it affects agriculture has been described by the IPCC, (2007), and cited by the US EPA (2011).

The increase in temperature will result to increased crop productivity in high latitude temperate regions due to the lengthening of the growing season and reduced crop productivity in low latitude subtropical and tropical regions where summer heat is already limiting productivity. Changes in amount of rainfall and patterns will affect soil erosion rates and soil moisture, which are important for crop yields. Precipitation will increase in high latitudes, and decrease in most subtropical low latitude regions-some by as much as about $20 \%$, leading to long drought spells. Rising atmospheric concentrations of $\mathrm{CO}_{2}$ will boost and enhance the growth of some crops but other aspects of climate change (e.g., higher temperatures and precipitation changes) may offset any beneficial boosting effect of higher $\mathrm{CO}_{2}$ levels. Agriculture will be potentially affected by changes in the frequency and severity of heat waves, drought, floods and hurricanes. This is currently being experienced in the United States and some EU countries. Climatic changes will affect agricultural systems and may lead to emergence of new pests and diseases due to migration [26].

Last year in Nigeria, new pests of tomato were identified and this caused loss of tomato fruits. The findings by the IPPC are very alarming. Unfortunately most Governments in the developing countries especially in sub Saharan Africa have failed to respond adequately to the threats of changes in climatic conditions which are invariably affecting global food security. Alternative agricultural practices suitable in different regions need to be established to reduce net greenhouse gas emissions while effectively maintaining or improving yields and adapting to more extreme weather. Climate change has an important impact on trans-boundary pest and diseases both for plant production and animal production. This will result in a higher probability of entry, establishment and spread of vector-borne diseases of animals, parasites of animals with free-living life stages, and pests of plants, diseases of fish and invasive alien aquatic species. For instance, a new strain of wheat stem rust is threatened major wheat producing countries. It was estimated by FAO that $80 \%$ of all wheat varieties planted in Asia and Africa are susceptible to this new virulent wheat fungus as it spreads rapidly mostly by wind and could seriously lower wheat production. This could lead to increased wheat prices and local or regional food shortages [1].

\section{Food Security}

Food security is the state achieved when food systems operate such that "all people, at all times, have physical and economic access to sufficient, safe and nutritious food to meet their dietary needs and food preferences for an active and healthy life" [37]. There are three dimensions of food security according to FAO: availability, access and utilisation. National food security implies that within a country the amount of food available, if evenly distributed, is enough to meet people's food needs [47]. At the household level, "a household is said to be food secure when it has access to the food required for a healthy life for all its members and when it is not at undue risk of losing such access" [48].

Sub-Saharan Africa is the only region where average food production per person has been declining over the last three decades, putting a large segment of the population at risk of food insecurity, starvation, malnutrition and extreme poverty [49]. Food insecurity and hunger leads to human health and economic development problems depriving the basic necessities of life. It leads to higher rates of child mortality and morbidity. The upsurge of the Boko Haram insurgents in Nigeria and some African countries made a lot of people food insecure and malnourished. Food insecurity and malnutrition result in serious public health problems and loss of human potential in developing countries [50].

The world food situation is presently very precarious. Obviously, therefore, sudden weather changes, plant epidemics, and animal diseases afflicting small geographic regions can upset global food supply. In order to increase agricultural production, a large number of countries are making major investments in bringing more land under irrigation. Good land resources however, are in short supply, except in Latin America. This has led to indiscriminate deforestation especially in developing countries, seriously threatening water regulation, and genetic diversity of plants and animals. By 2020, the world's farmers will have to produce $40 \%$ more grain (200 million extra tons in the developed countries and 500 million extra tons in the developing countries [51].

\section{Mitigating the Effects of Climate Change using Modern Biotechnology}

The Cartagena Protocol on Biosafety (BSP) is an international treaty under the United Nations Convention on Biological Diversity (CBD) which came into force on 11 September, 2011. It 
defines modern biotechnology to mean the application of in vitro nucleic acid techniques, or fusion of cells beyond the taxonomic family, that overcome natural, physiological, reproductive or recombination barriers. The goal of the protocol is to protect biological diversity from potential risks posed by introduction of living modified organisms (LMOs), which is the Protocol's way of referring to genetically modified organisms (GMOs), resulting from modern biotechnology. This technique is unique as it allows scientists to precisely introduce a desired trait by inserting only specific genes into plants and animals for improvement of specific traits.

Genes can be transferred from one species to another which was impossible with the conventional breeding methods. In certain areas, biotechnology and genetic modification techniques are being optimized for the production and development of healthy foods, and improvement in the levels of essential minerals and vitamins through the process of biofortification. While there has been some hesitation with regard to the acceptability and adoption of biotechnology products in certain developing countries in Africa including Nigeria, some gains have been made such as the development of high-vitamin A rice (Golden rice) and the recent development of two varieties of vitamin A- rich cassava lines (UMUCASS 42 and UMUCASS 43) in Nigeria through conventional means. The varieties were developed through a collaborative effort between the International Institute of Tropical Agriculture (IITA) and the Nigerian Root Crops Research Institute (NRCRI).

Nigeria, have greatly increased the acceptability of biotechnology for human food applications among hitherto skeptical consumers. Crops can be modified faster through modern biotechnology than conventional breeding, thus hastening implementation of strategies to meet rapid and severe climatic changes. Plant scientists are developing droughttolerant and water-efficient crops that can maintain and provide higher yields. They are also working to develop genetically modified crops, like maize or potatoes, to be water-efficient less water, or to be drought-tolerant, while still keeping the qualities of the crop that consumers are used to, such as taste, colour, shape and smell and saving precious water resources in certain farming areas where water is a serious limitation. Plant scientist are also producing plants that use nitrogen more efficiently, reducing the need for added fertilizer, and thereby reducing greenhouse gas (GHG) emissions [52].

Genetically engineered rice and canola varieties that use nitrogen more efficiently with less fertilizer applications have been developed [53]. Many supportive policies have also been put in place for the production and utilisation of biofuels, particularly bioethanol both from traditional and GMO crops such as sugarcane, oilseed, rapeseed, and jatropha which will help to reduce the adverse effects of $\mathrm{CO}_{2}$ emission by the transport sector [17]. Biodiesel from Jatropha and Palm oil $[18,54]$, bioethanol from sugarcane $[9,54,55]$ and biogas from wastes [9] have assisted greatly in reducing carbon sequestration. Carbon sequestration is the capture or uptake of carbon containing compounds such as carbon dioxide. It is commonly used to describe any increase in soil organic carbon content caused by change of land management, with implication that the increased soil carbon storage mitigates climate change [56]. The adoption of herbicide-tolerant crops, such as Roundup Ready soybeans, and canola $[7,8]$, permit farmers to substitute application of broad spectrum herbicides, like glyphosates, for tilling operations that not only degrade the soil and potentially increase farm chemical run-off, but also reduce soil carbon sequestration.

The use of genetically modified Roundup Ready TM (herbicide resistant) soybean technology has accounted for up to $95 \%$ of no-till area in the United States of America (USA) and Argentina leading to sequestration of 63,859 million tonnes of $\mathrm{CO}_{2}$ and led to sequestration of 63,859 million tonnes of $\mathrm{CO}_{2}$ [6-8]. The modified crops reduced the need for tillage or ploughing to allow farmers to adopt no-till farming practices. Thus, farmers build up the nutrients in their fields, preserve topsoil and keep carbon in the soil. Also, no-till reduces the number of tractor passes in the field to cut tractor fuel. For 2011, Brookes and Barfoot, [57] reported that there was a reduction of 37 million $\mathrm{kg}$ of active ingredients, decreased rate of herbicide and insecticide sprays and ploughing reduced $\mathrm{CO}_{2}$ emission by 23.1 billion $\mathrm{kg}$ of $\mathrm{CO}_{2}$ or removing 10.2 million cars off the road. Herbicide tolerant crops allow farmers to use non-selective chemicals to control weeds after crop emergence, thereby reducing the risks associated with conservation tillage or no-till strategies [9].

This also significantly reduces carbon sequestration and $\mathrm{CO}_{2}$ emissions, reduces fuel use, and significantly reduce soil erosion while insect resistant biotech crops require fewer pesticide sprays which invariably results in savings of tractor/fossil fuel and thus less $\mathrm{CO}_{2}$ emissions [10]. Pest and disease resistant biotech crops have continuously developed as new pests and diseases emerge with changes in climate. Resistant varieties will also reduce pesticide application and hence $\mathrm{CO}_{2}$ emission. $\mathrm{Bt}$ maize and $\mathrm{Bt}$ cotton have been developed and now in the commercial market in South Africa and the United States [11]. Crops tolerant to various abiotic stresses have been developed in response to climatic changes. Marker assisted breeding for stress resistance has been achieved for drought tolerant crops such as maize and hybrid wheat [58], GM Arabidopsis, tobacco, maize, wheat, cotton, and soybean $[13,14,16]$.

Transgenic crops carrying different drought tolerant genes are being developed in rice, wheat, maize, sugarcane, tobacco, groundnut, tomato, and potato. In Australia for example, field trials of 1,161 lines of genetically modified (GM) wheat and 1,179 lines of GM barley modified to contain one of 35 genes obtained from wheat, barley, maize, thale cress, moss or yeasts were in progress since 2010 and ran till 2015. Similarly, transgenic plants carrying genes for water-stress management have been 
developed. An important initiative for Africa is the Water Efficient Maize for Africa (WEMA) project of the Kenyan-based African Agricultural Technology Foundation (AATF) and funded by the Bill and Melinda Gates Foundation (BMGF) and Howard G. Buffet Foundations. This project is expected to maintain and double the yield of maize grown under drought conditions. Salt tolerant GM tomato and rice [12] as well as heat tolerant GM Arabidopsis and GM Brassica [13] have been developed. The University of Florida developed heat-tolerant biotech traits that showed yield increases of $38 \%$ in wheat, $23 \%$ in rice and $68 \%$ in maize grown in extreme and unexpected hot conditions [52].

However, most countries in Africa are yet to accept this useful technology. Africa needs to identify specific biotechnology priority areas that offer high potential for contributing to the economy and people's livelihood, alleviating poverty, enhancing food security, reducing impact of biotic and abiotic stresses which will mitigate the effects of climate change and seek to promote Africa-focused biotechnology [59]. As at 2013, only South Africa, Burkina Faso and Sudan accepted modern biotechnology and hence have Biosafety laws in place to regulate it. Burkina Faso and Sudan increased biotech cotton hectarage by an impressive 50 percent and 300 percent, respectively [10]. Also, seven additional countries are conducting biotech crop field trials as the penultimate step to approval for commercialization. These countries include: Cameroon, Egypt, Ghana, Kenya, Malawi, Nigeria and Uganda [10]. In April 2015, the Nigerian Government approved the Biosafety bill which will permit the safe use of modern biotechnology in Nigeria, Africa's most populous country.

\section{Biosafety Measures and Government Policies}

Safe development of biotechnologies depends on clear national policies. Currently, 45 African countries have ratified the Cartagena Protocol of Biosafety [60] and many are developing regulatory systems for modern biotechnology applications. Only within such a framework can African countries map their own path to food security in the face of climate change. Biosecurity and Biosafety systems are key to maximizing the benefits from biotechnology because they demonstrate to stakeholders and the public that attendant environmental and health issues are addressed by scientific risk assessments [61,62]. Biosafety laws must be put in place to ensure that the crops released are environmentally safe.

The end users the farmers need to be educated on the benefits of modern biotechnology in crop improvement as their confidence in Government would hasten acceptability. Well trained scientists in this expanding field of biological research are therefore required to enhance economic growth and sustain food security in sub Saharan Africa. The importance of biotechnology in agricultural productivity is gaining more acceptances by African Governments but the political will is needed to sign the Biosafety law and implement it. Africa is often faced with the monster called corruption.
For efficient regulation and implementation of biosafety laws and ensure biosecurity, zero tolerance for corruption by the relevant agencies must be upheld. It is also necessary that public-private partnership be considered for efficient utilisation of modern biotechnology for mitigating climate change and enhancing food security. The government cannot handle it alone especially in African countries. The emission of GHGs can be reduced with the formulation of good policies on agricultural development with the use of sustainable agricultural biotechnology. This should however be done with strict adherence to the biosafety laws to ensure there is no harmful effect on man and the environment. The Governments especially in developing countries in Africa should intensify its sensitization campaign on the use of biotechnology for agricultural productivity and mitigation of climate change. The Open Forum for Agricultural Biotechnology (OFAB) has being sensitizing the populace on the importance of modern biotechnology through seminars and workshops. Universities and Agencies involved in biotechnology as well as various African governments and policy makers should take a cue from this. The more enlightened the farmers are, the easier it is for them to accept the technology.

\section{Conclusion}

Concurrent efforts are required to establish a sustainable global food system with climate-resilient agricultural production systems, efficient use of resources, low-waste supply chains, and more consumer choice for healthy diets. Agricultural production should be intensified and must be accompanied by concerted efforts to reduce greenhouse gas emissions from agriculture to avoid further acceleration of climate change and avert threats to the long-term viability of global agriculture. Improved crops via agricultural biotechnology, resilient to extreme environments caused by climate change are expected over the years. Biotechnology contributes to poverty alleviation by increasing crop productivity and income generation, particularly for resource-poor farmers, and brings about a safer environment and more sustainable agricultural development.

Hence, food production during this era should be given another boost to sustain food supply for the doubling population. According to the former United States President Jimmy Carter, 'Responsible biotechnology is not the enemy; starvation is. Without adequate food supplies at affordable prices, we can't expect world health or peace.' Biotechnology research to mitigate climate change should be initiated to sustain the utilisation of new products. Since changes in climate also brings about the presence of new pests and diseases to regions where they did not exist, entomologists and pathologists will need to keep on searching for new ways to eradicate such pests and pathogens so that National food security is not affected.

\section{References}

1. FAO (2008) Wheat killer detected in Iran. Dangerous fungus on the move from East Africa to Middle East. FAO Newsroom, Italy.

2. WFP (World Food Programme) (2012) 'Who are the hungry?' Online. African Smallholders Farmers Group, Africa. 
3. WHO (World Health Organization) (2009) Global prevalence of vitamin A deficiency in populations at risk 1995-2005. WHO global database on vitamin A deficiency. Geneva, Switzerland.

4. Harvest Plus (2011) Breeding crops for better nutrition.

5. Treasury HM (2009) Green biotechnology and climate change. Euro Bio, Europe, p.12.

6. Fawcett R, Towry D (2002) Conservation Tillage and Plant Biotechnology: How New Technologies Can Improve the Environment by Reducing the Need to Plow. Conservatory Technology Information Center, West Lafayette, Indiana, pp. 1-24.

7. Brimner TA, Gallivan GJ, Stephenson GR (2004) Influence of herbicideresistant canola on environmental impact of weed management. Pest Manag Sci 61(1): 47-52.

8. Kleter GA, Harris C, Stephenson G, Unsworth J (2008) Comparison of herbicide regimes and the associated potential environmental effects of glyphosate-resistant crops versus what they replace in Europe. Pest Manage Sci 64(4): 479-488.

9. Sexton S, Zilberman D (2010) Agricultural Biotechnology Can Help Mitigate Climate Change. ARE Update 14(2): 1-4.

10. ISAAA Global Knowledge Center on Crop Biotechnology (2014) Pocket K No. 43: Biotechnology and Climate Change.

11. Zhe D, Mithcell PD (2011) Can conventional crop producers also benefit from Bt technology? Agricultural and Applied Association series 103584 .

12. Zhang HX, Blumwald E (2002) Transgenic salt-tolerant tomato plants accumulate salt in foliage but not in fruit. Nature Biotech 19(8): 765768.

13. Jaglo KR, Kleff S, Amundsen KL, Zhang X, Haake V, et al. (2001) Components of the Arabidopsis C-repeat/ dehydration-responsive element binding factor cold-response pathway are conserved in Brassica napus and other plant species. Plant Physiol 127(3): 910-917.

14. Yamanouchi U, Yano M, Lin H, Ashikari M, Yamada K (2002) A rice spotted leaf gene Sp17 encodes a heat stress transcription factor protein. Proc Natl Acad Sci 99(11): 7530-7535.

15. Wang W, Vinocur B, Altman A (2003) Plant responses to drought, salinity and extreme temperatures: Towards genetic engineering for stress tolerance. Planta 218(1): 1-14

16. Manavalan LP, Guttikonda SC, Tran LP, Nguyen HT (2009) Physiological and molecular approached to improve drought resistance in soybean. Plant cell Physiol 50(7): 1260-1276.

17. Sarin R, Sharma M, Sinharay S, Malhotra RK (2007) Jatropha-palm biodiesel blends: An optimum mix for Asia. Fuel 86(10-11): 13651371.

18. Lua H, Liua Y, Zhoua H, Yanga Y, Chena M, et al. (2009) Production of biodiesel from Jatropha curcas L. oil. Comp. Chem Eng 33 (5): 10911096.

19. Jain S, Sharma MP (2010) Prospects of biodiesel from Jatropha in India: A review. Renew sustain Ene Rev 14(2): 763- 771.

20. Lybbert T, Sumner D (2010) Agricultural technologies for climate change mitigation and adaptation in developing countries: Policy options for innovation and technology diffusion. ICTSD-IPC Platform on Climate Change, ATS Policy Brief 6.

21. Beddington J, Asaduzzaman M, Clark M, Fernandez A, Guillou M, et al. (2012) Achieving food security in the face of climate change: Final report from the Commission on Sustainable Agriculture and Climate Change. CGIAR Research Program on Climate Change, Agriculture and Food Security (CCAFS), Copenhagen, Denmark.

22. Gemeda DO, Sima AD (2015) The impacts of climate change on African continent and the way forward. J Eco Nat Env Rev 7(10): 256-262.
23. Stern NH (2006) The economics of climate change: the Stern review. Cambridge University Press, Cambridge, UK.

24. Iloh A, Gidado R (2016) A Nigerian perspective: GMO crops can reduce climate change impacts. Cornell Alliance.

25. Global Carbon Project (GCP) (2008) Carbon reductions and offsets. Report no 6.

26. IPCC (Intergovernmental Panel on Climate Change) (2014) IPPC Fifth Assessment Report.

27. Lobell DB, Burke MB (2008) Why are agricultural impacts of climate change so uncertain? The importance of temperature relative to precipitation. Env Res Lett 3(034007): 8.

28. Parry M, Arnell N, Berry P, Dodman D, Fankhauser S, et al. (2009) Assessing the Costs of Adaptation to Climate Change: A Review of the UNFCCC and Other Recent Estimates, International Institute for Environment and Development and Grantham Institute for Climate Change, London.

29. Deressa TT, Hassan T (2010) Economic Impact of Climate Change on Crop Production in Ethiopia: Evidence from Cross-section Measures. J Afr Econ 18(4): 529-554.

30. Brown ME, Funk CC (2008) Food security under climate change. Sci 319: 580-581.

31. UNEP (2010) Assessing the Environmental Impacts of Consumption and Production: Priority Products and Materials, A Report of the Working Group on the Environmental Impacts of Products and Materials to the International Panel for Sustainable Resource Management.

32. Barfoot P, Brookes G (2006) GM crops: the first ten years-Global socioeconomic and environmental impacts on Nigeria.

33. Bruckner M (2012) Climate change vulnerability and the identification of least developed countries (LDCs). The United Nations Development Policy and Analysis Division Department of Economic and Social Affairs, pp. 3-15.

34. Thomton PK, Jones PG, Ericksen PJ, Challinor AJ (2011) Agriculture and Food System in Sub-Saharan Africa in a $4^{\circ} \mathrm{C}+$ World, Philosophical Transactions. The Royal Society A 369: 117-136.

35. Barr RS, Fankhauser K, Hamilton (2010) Adaptation investments: a resource allocation framework.

36. Mitigation and Adaptation Strategies for Global Change. 15: 843-858.

37. Hummel D (2015) Climate Change, Land Degradation and Migration in Mali and Senegal-some Policy Implications, Migration and Development. Institute of Social-Ecological Research, Hamburger Allee 45, 60486 Frankfurt/Main, German.

38. Quaye W, Yawson RM, Ayeh ES, Yawson I (2012) Climate change and food security: The role of biotechnology. Afr J Food Agric Nut Dev 12(5): 6354-6364.

39. Dinar A, Hassan R, Kurukulasuriya P, Benhin J, Mendelsohn R (2006) The policy nexus between agriculture and climate change in Africa A synthesis of the investigation under the GEF/WB Project: Regional climate, water and agriculture: Impacts on and adaptation of agroecological systems in Africa. CEEPA Discussion, p. 39.

40. Fischer G, Shah M, van Velthuizen H (2008) Climate change and agriculture in Africa. Options Summer, pp. 16-17.

41. Tetteh EM, Opareh NO, Ampadu R, Antwid KB (2014) Impact of Climate Change: Views and Perceptions of Policy Makers on Smallholder Agriculture in Ghana. Int J Sci Basic Appl Res 13(1): 79-89.

42. Shah MM, Fisher G, Velthuizen H (2008) Food Security and Sustainable Agriculture. The Challenges of Climate Change in sub-Sahara Africa International Institute for Applied Systems Analysis Laxenburg, Austria. 
43. Odjugo PA (2010) General Overview of Climate Change Impacts in Nigeria. J Humid Eco 29(1): 47-55.

44. BNRCC (Building Nigeria's Response to Climate Change) (2014) Reports of Climate Change Adaptation Research in Niger Delta.

45. Olaniyi OA, Ojekunle ZO, Amujo BT (2013) Review of Climate Change and Its Effect on Nigeria Ecosystem. Int J Afr Asian Stud 1: 57-65.

46. IPCC (Intergovernmental Panel on Climate Change) (2007), Climate Change 2007-Synthesis Report. Summary for Policymakers 24: 530533.

47. Building Nigeria's Response to Climate Change (BNRCC) (2008) 2008 Annual Workshop of Nigerian Environmental Study Team (NEST): The Recent Global and Local Action on Climate Change, held at Hotel Millennium, Abuja, Nigeria.

48. Tonukari NJ, Omotor DG (2010) Biotechnology and food security in developing countries. Biotech Mol Bio Rev 5(1): 13-23.

49. UN ACC/SCN (United Nations Administrative Committee on Coordination- Subcommittee on Nutrition) (1991) Brief on policies to alleviate under consumption and malnutrition in deprived areas. Geneva.

50. Fikremarkos BM (2010) Biotechnology and the Future of Africa's Agriculture (June 30, 2010). Society of International Economic Law (SIEL), Second Biennial Global Conference, University of Barcelona.

51. Pinstrup-Anderson P, Cohen M (2000) Modern Biotechnology for Food and Agriculture: Risks and Opportunities for the Poor. In: GJ Persley and MM Lantin (Eds.), Agricultural Biotechnology and the Poor. An International Conference on Biotechnology, CGIAR, Washington DC USA, pp. 159-169.

52. Chrispeels MJ (2000) Biotechnology and the Poor. Pl Physiol 124: 3-6.
53. Crop for life (2015) Five tools to tackle climate change.

54. Johnsona JMF, Franzluebbersb AJ, Weyersa SL, Reicoskya DC (2007) Agricultural opportunities to mitigate greenhouse gas emissions. Env Poll 150(1): 107-124.

55. Jain S, Sharma MP (2010) Prospects of biodiesel from Jatropha in India: A review. Renewable and sustainable Energy Rev 14(2): 763- 771.

56. Lybbert T, Sumner D (2010) Agricultural technologies for climate change mitigation and adaptation in developing countries: Policy options for innovation and technology diffusion. ICTSD-IPC Platform on Climate Change.

57. Powlson DS, Whitmore AP, Goulding KWT (2011) Soil carbon sequestration to mitigate climate change: a critical re-examination to identify the true and the false. Eur J Soil Sci 62: 42-55.

58. Brookes G, P Barfoot (2012) Global economic and environmental benefits of GM crops continue to rise.

59. Wang W, Vinocur B, Altman A (2003) Plant responses to drought, salinity and extreme temperatures: Towards genetic engineering for stress tolerance. Planta 218(1): 1-14.

60. Nyange NE, Kingamkono RR, Kullayaand AK, Mneney EE (2011) Biotechnology for sustainable agriculture, food security and poverty reduction in Africa.

61. NEPAD ABNE (2010) Status of crop biotechnology in Africa Online.

62. Chikaire J, Nnadi FN, Ejiogu-Okereke N, Echetama JA (2012) Agricultural biotechnology and bio-safety: tools for attaining food security and sustainable industrial growth in Nigeria. Cont J Agric Sci 6(1): 6 .

\section{Your next submission with Juniper Publishers} will reach you the below assets

- Quality Editorial service

- Swift Peer Review

- Reprints availability

- E-prints Service

- Manuscript Podcast for convenient understanding

- Global attainment for your research

- Manuscript accessibility in different formats

(Pdf, E-pub, Full Text, Audio)

- Unceasing customer service

Track the below URL for one-step submission https://juniperpublishers.com/online-submission.php 